\section{THE EFFECT OF IONS UPON AGGLUTINATION.}

BX TAKUJI SHIONOYA, M.D.

(From the Laboratory of the Medical Clinic of Prof. K. MruRA, at the Medical College, Imperial University, Tokyo.)

\section{Introduction.}

Tut true mechanism of agglutination is still unknown. The first investigation upon it was described in 1899 by Bordet, ${ }^{1}$ who showed that for the occurrence of the phenomenon not only the combination of agglutinin and bacteria, but also the presence of sodium chloride, is needed. Bordet found that if the salt was removed from the serum and from the suspension of bacteria by dialysis, and the serum and suspension mixed, agglutination did not oecur, but that if a small amount of sodium chloride was added, agglutination promptly took place. According to this view agglutination is a phenomenon of molecular physics - the agglutinin acts on the bacteria or other cells and prepares them for agglutination by altering the relations of molecular attraction between them and the surrounding fluid, whilst the second phase, the loss of motility, clumping, \&c., is brought about by the presence of salts as is the sedimentation of clay. Joos ${ }^{2}$ observed that agglutinin was absorbed by bacteria. When the agglutinin-bacteria combination was precipitated by salt, he found that the concentration of salt in the supernatant fluid was decreased, so that he believed that true chemical action took place in agglutination. He distinguished two phases, primary and secondary, of the phenomenon : the absorption of agglutinin by agglutinable substance, and the precipitation of salt with the agglutinin-bacteria combination. Furthermore, he observed that in the secondary phase the precipitating action differs according to the kind of salt, chloride, iodide, bromide, \&c., with monovalent cations, and believed that the acid radicals of salts took an important part in the action of precipitation.

Neisser and Friedemann, ${ }^{3}$ Bechhold ${ }^{*}$ and Friedberger, ${ }^{5}$ investigated the precipitation of inorganic suspensions and of the colloids by several salts which possess negative electric charges, examined the limiting concentration of salt solution in which the action of precipitation took place in 24 hours, and proved distinctly that the really important factor in its action is the cation and not the anion. In addition to the agglutinin and bacteria, therefore, the presence of some cation is necessary for the mechanism of agglutination. In their experiments Joos ${ }^{2}$ and Friedberger $^{5}$ did not, however, use equivalent solutions, while Neisser and Friedemann, ${ }^{3}$ and Bechhold used only various light metal salts, and their solutions were equivalent. To fill up these gaps, Porges ${ }^{6}$ made use of the fact that the absorption of agglutinin by bacteria may be produced in the salt-free medium. He added toluol to a suspension of typhoid-agarculture in distilled water, and to typhoid immunised serum, and dialysed each in running water for three days and in distilled water for two days more. After having ascertained that the water was free from chlorine ions, he mixed each 1 c.cm. of bacteria suspension with $0.5 \mathrm{c.cm}$. diluted serum and various diluted salt solutions, and observed the limiting concentration of salt in which the agglutination takes place. During his experiments with various dilutions of a normal solution of $\mathrm{NaCl}, \mathrm{KCl}, \mathrm{NH}_{4} \mathrm{Cl}, \mathrm{MgCl}_{\text {. }}$ $\mathrm{NaNO}_{3}, \mathrm{KNO}_{3}, \mathrm{NH}_{4} \mathrm{NO}_{3}, \mathrm{Mg}\left(\mathrm{NO}_{3}\right)_{2}, \mathrm{Na}_{2} \mathrm{SO}_{4}, \mathrm{~K}_{2} \mathrm{SO}_{4}$, $\left(\mathrm{NH}_{4}\right)_{2} \mathrm{SO}_{4}, \mathrm{MgSO}_{4}$, he observed the relation between anions and cations and found that there is only small difference between $\mathrm{Cl}^{\prime}, \mathrm{NO}_{3}^{\prime}$ and $\mathrm{SO}_{4}^{\prime \prime}$, but that the effect of $\mathrm{Mg} \cdot$ is 10 times greater than other cations. Buxton and Shaffer, ${ }^{7}$ and Buxton and Teague, ${ }^{8}$ also examined the precipitation of colloids with some simple common salts of mono- to trivalent cations (for example $\mathrm{Al} \cdots, \mathrm{Fe}{ }^{\cdots}$, \&c.), and proved that there is no difference between the precipitation of agglutininbacteria combination and that of inorganic colloids.
The results thus obtained show not only that the agglutination is a physico-chemical phenomenon in which the presence of salts is necessary, but also that these cations play an important part in it.

Such experiments with cations of a valency greater than three had not hitherto been tried, but it was evident that the agglutination is closely related to the valency rule. Accordingly an attenpt was made, under the guidance of Prof. K. Miura, to investigate the effect of the valency of salts on the phenomenon of agglutination, and to examine the effect of cations thereon in the following manner.

\section{Irethod of Research.}

(A) Ayulutinin-bacteria combination.-Porges ${ }^{6}$ examined the precipitating action of salts by mixing them with the dialysed serum and hacteria, but as serum is of a complex nature it is not suitable for the investigation of the effect of ions. For my experiments I have prepared the salt-free agglutinin-bacteria in the following manner: Typhoid strains were prepared on 16 to 24 hour slope agar cultures, and the bacilli from 10 cultures suspended in $10 \mathrm{c.cm}$. of sterilised notmal saline solution, care being taken to prevent admixture of agar or condensed water in the agar tube. To this suspension was added $1 \mathrm{cccm}$. of typhoid immunised serum with an agolutination titre of $1: 10,000$. After placing in the thermostat for 30 minutes, 20 c.cm. distilled water were added and the combination centrifugalised ; the supernatant fluid was remored, a further $20 \mathrm{c.cm}$. of distilled water added and the mixture again centrifugalised. 'The washing by centrifugalisation was repeated five times; the mixture was then placed in a dialysation shell, $40 \mathrm{c.cm}$. of distilled water were added, and the mixture dialysed in running water for five days, and in distilled wate for two days, in order to free it completely from chlorino ions. A milky-white and diffusely turbid suspension of agolutinin-bacteria combination was obtained and used in the experiments as follows: Into a series of small test-tubes (previously boiled to free from alkaline matter and electrolytes) was put 1 c.cm. of various salt solutions in different concentration, and to each tube was added one drop of the agglutinin-bacteria suspension (each drop containing about one normal platinum loopful of the bacteria). After well mixing they were kept in the thermostat at $37^{\circ} \mathrm{C}$. for two hours and afterwards at the room temperature for 18 hours. Macroscopic observation showed that the agglutinin-bacteria combination was precipitating in the bottom of the tube, while the supernatant fluid was clear ; the fluid was more concentrated than the precipitation limit, for if its concentration was lower than the limiting value, it would not have clumped, and the supernatant liquid would have remained turbid. The spontaneous agrlutination is to be distinguished easily from the ordinary agglutination phenomenon, for in the case of the former, mere shaking makes the fluid turbid.

(B) Sults.-Matsuno ${ }^{9}$ found when investigating the effect of cations upon arsenious sulphide, that simple salts are not appropriate materials for the investigation of the effect of valency on the coagulation of colloidal arsenious sulphide. For example, the concentration of cupric sulphate passes over bevond the limiting value of other bivalent salts as shown on Table I. It dissociates perhaps not only as the formula-

$$
\mathrm{CuSO}_{4} \rightleftarrows \mathrm{Cu} \cdot+\mathrm{SO}_{4}^{\prime \prime},
$$

but the hydrolysis would also take place partially in form of-

$$
2 \mathrm{CuSO}_{4}+2 \mathrm{H}_{2} \mathrm{O} \rightleftarrows \mathrm{Cu}_{2}(\mathrm{OH})_{2} \mathrm{SO}_{4}+\mathrm{H}_{5} \mathrm{SO}_{4},
$$

so that its aqueous solution displays a faint acid reaction. To avoid this inconvenience it was necessary to search for salts with cations of several valencies. The bivalent or trivalent salts are common, but tetravalent salts are difficult to obtain, and pentavalent salts are still unknown. Prof. Shibata of the College of Science, Imperial University, Tokyo, was kind enough to furnish me with cobaltic complexes for this purpose. Though pentavalent salts are unknown 
When $n=1,-\log S_{1}=a$, the equation (1) will be now,

$\log S_{n}+\beta \log n-\log S_{1}=0$

The value of $\beta$ in the above equation can be calculated from the equation,

$$
\beta=\frac{\log \mathbf{S}_{\mathbf{1}}-\log \mathbf{S}_{\mathbf{n}}}{\log n}
$$

FIG. 3.

substituting the experimental data for $S_{1}$ and $\mathbf{S}_{11}$. The results of calculation was as follows :-

$$
\begin{array}{ccc}
\text { For bivalent ions } & \ldots & 3.733 \\
\text {, trivalent ions } & \ldots & 3.620 \\
\text { " tetravalent ions } & \ldots & 3.821 \\
\text { " hexavalent ions } & \ldots & 3.628 \\
\text { Aver. } & \ldots & 3.7
\end{array}
$$

This number is applicable only in the case of agglutination of the combination of typhoid bacilli with its agglutinin in the solution of cobaltio complexes.

Putting $\beta=3 \cdot 7$ in the equation (2), the equation was deduced:- $-\log S_{n}=\log S_{1}-3 \cdot 7 \log n$. It gave:-

Limiting value equivalent concentrations.

\begin{tabular}{clllc} 
Valency. & \multicolumn{2}{c}{ Observed. } & Calculated. \\
1 & $\ldots$ & $1 / 150$ & $\ldots$ & - \\
2 & $\ldots$ & $1 / 2000$ & $\ldots$ & $1 / 1950$ \\
3 & $\ldots$ & $1 / 10000$ & $\ldots$ & $1 / 8738$ \\
4 & $\ldots$ & $1 / 30000$ & $\ldots$ & $1 / 25336$ \\
5 & $\ldots$ & $1 / 100000$ & $\ldots$ & 1,113508
\end{tabular}

In comparing the calculated limiting values with those obtained by experiment, it is found that close conformity exists.

Since the experiments with common simple salts, for example, CuSO ${ }_{4}$, gave by reason of hydrolysis instead of a straight line a curve, they are not suitable materials for the observation of effect of valencies of salts upon agglutination. The precipitation of agglutinin-bacteria combination is produced through the force of certain amounts of cations and that precipitation follows the valency rule in the same manne as in the case of precipitation of inorganic colloids.

\section{Summary.}

1. A pure salt free agglutinin-bacteria combination has been prepared by repeated washing of the agglutinin-bacteria mixture with distilled water and subsequent dialysis. As the common simple salts are not suitable, owing to hydrolysis and other causes, for the purpose of testing the effect of ions, the cobaltic complexes of valency from 1 to 6 were used, with which the author has been able to test the effect of positive complex ions.

2 . It has been found that the more the valency of the cation (from 1 to 6 ) increases, the less becomes the limiting concentration with which agolutination takes place; further, it has been found that there exists such close relation between them that when a logarithmic curve is plotted of the limiting values and of the valencies, a straight line is formed. The precipitating action of the agglutinin-bacteria combination is entirely in accordance with the valency rule, and the author has proved that as precipitation occurs through the action of cations, it is a colloid bcaring negative electric charges.

The autbor wishes to express his indebtedness to Prof. K. Miura for guidance and encouragement in this research, to Mr. Y. Shibata, Professor at the College of Science, for much valuable material, and to Dr. T. Itakura for helpful advice.

Addendum.-The above-mentioned findings are not only applicable to the agglutination of the agglutinin-bacteria combination by salts but the same relations seem to appear in the case of hæmagglutination, which is at present in the course of investigation and will be published in a later report.

(Continued at foot of next column.)

\section{SATURNINE ASTHMA :}

IS THERE SUCI A MALADY?

By Sir THOMAS OLIVER, M.D.GLAsG., F.R.C.P. LOND.,

PROLESTOR OF THE PRINGIPIES AND PRICTIOE OF MHDICINA,

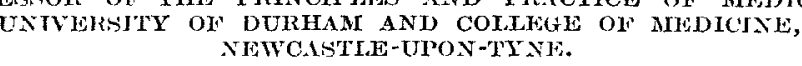

Is there such a malady as saturnine asthma?

History of Case.-'Twenty-two years ago I examined for a life insurance company, and passed as a first-class life, a male aged 21. Ten years afterwards he was examined by another medical man for another office, and again was passed as a first-class life. Eight years ago he had pleurisy from which he was said to have made a good recovery. He had good health until 1918 when he began to suffer from shortness of breath on going up an incline. The dyspnoea came on gradually and was believed by the medical men who saw him to be the result of cardiac overstrain. Rest was prescribed but instead of following out this instruction, patient went on with his business. During 1918 he was attached to the anti-aircraft service, and regularly took his share of night work, attending to office duties during the day. When thus engaged he again began to experience shortness of breath. In January, 1919, he developed bronchitis, in the course of which asthma supervened. Six months afterwards, as tubercle bacilli were found in the sputum, patient was sent to a sanatorium in Scotland, where he was informed that his malady was not bronchitis and asthma, but that the so-called asthma was due to some toxic cause, the nature of which was not ascertained.

Prior to this the patient had been losing weight, but during the three months he was in the sanatorium in 1919 he gained $22 \mathrm{lb}$. in weight and came home. In September, 1920, he returned to the sanatorium. It was now noticed that his finger-nails were black. Vomiting at this stage supervened, and after a residence of three months in the sanatorium tachycardia developed. At the time no explanation was forthcoming as to the blackening of the finger-nails, the vomiting, and tachycardia. The asthmatic seizures kept recurring and were severe. After a rest in bed for several weeks the cardiac condition considerably improved. To iodide of potassium, given to relieve the asthma, patient exhibited marked intolerance; instead of giving relief it brought on respiratory spasm attended by an acute rash on the skin. At this stage he consulted a London physician.

Last February he was sent to me by Dr. John Macfadyen of Newcastle-on-Tyne. On examining the patient wheezing râles could be heard pretty well all over the chest attended by prolonged expiration; over the right apex posteriorly dry friction could be heard, with here and there small moist râles. There was

(Continued from previous column.)

BrBLIOGRAPHY.

1. Bordet : Mechanisme de l'agglutination, Annales de I'asteur, 1899

2. Joos: Untersuchungen über die Bedeutung der Salze bei der Aggl. Zeitschrift $f$. Hygiene, Bd. 36 ; Tntersuchungen über den Mechanismus der Agglutination, Zeitschrift $f$. Hygiene, Bd. 40 .

3. Neisser u. Friedemann : Studien über Ausflockungserscheinungen, Münch. Ned. W., Nr. 11, 1904; Studien über Ausflock ungserscheinungen, iünch. ired. W., Nr. 10, 1904

4. Bechhold: Die Ausflockung von Suspension bez. Kolloiden u. die Bakterienagglutination, $\mathrm{Z}$. $\mathrm{f}$. phys. Chem., Bd. 48 .

5. Friedberger : Untersuchungen ûber die Bedeutung der Salze für die Agglutination, C. f. Bakt., Bd. 30, 1901; Ueber doide auf die Agghtination der Bakterien, C. f. Bakt., Bd. 31, loide

6. Porges: Teber die Beziehungen zwischen Bacterienagglutination u. Ausflockungserscheinungen der Kolloide, $C_{\text {. }} \mathbf{f}$ Bakt., Bd. 40,1906

7. Buxton $\mathrm{u}$. Shaffer : Die Agglutination in physik. Hinsicht. Z. f. phys Ch. Shaffer : Dis

8. Buxton $u$. Teague : Die Agglutination in physik, Hinsicht. f. phys. Chem., Bd. 57,64.

9. Matsuno: The Coagulation of Arsenious Sulphide Sol by Cobaltic Complexes, Journal of Tokro Chem. Society, No. 10,

10. Freundlich : Zeitschrift für physikalische Chemie, Bd. 44, 11. Whetham : Phil. Mag., 1899, 48, 474. 